\title{
Preliminary selection of acerola genotypes in Brazil
}

ítalo Herbert Lucena CAVALCANTE ${ }^{a}$, Márkilla Zunete BeCKMANNa ${ }^{a}$, Antonio Baldo Geraldo MARTINS ${ }^{a}$, Milton César Costa CAMPos ${ }^{b}$

\author{
a Department of Phytotechny, \\ Universidade Estadual \\ Paulista, Via de Acesso Prof \\ Paulo Donato Castellane, $\mathrm{s} / \mathrm{n}$, \\ 14884-900, Jaboticabal, \\ São Paulo, Brazil \\ italohlc@fcav.unesp.br \\ b Department of Soil Science, \\ Universidade Estadual \\ Paulista, Via de Acesso Prof \\ Paulo Donato Castellane, $\mathrm{s} / \mathrm{n}$, \\ 14884-900, Jaboticabal, \\ São Paulo, Brazil
}

\section{Preliminary selection of acerola genotypes in Brazil.}

Abstract - Introduction. Breeding studies for acerola (Malpighia glabra) improvement aim at obtaining plants that produce fruits with uniform chemical and physical attributes, including high levels of vitamin C, which can provision the market with fresh fruit and frozen pulp. High variability in fruit quality is observed in Brazilian acerola crops, especially those propagated by seeds. In this context, the objective of our research was to evaluate the physical and chemical characteristics of Brazilian acerola genotype fruits. Materials and methods. Sixteen acerola genotypes were studied in Jaboticabal, São Paulo State, Brazil. A completely randomized design with sixteen treatments and six replications was adopted. Each treatment was represented by one genotype. Several parameters related to fruit quality, such as width, length, weight, pulp percentage, soluble solids (SS), titratable acidity (TA), [SS / TA] ratio and vitamin C content, were evaluated in fruits of the acerola genotypes. The results were submitted to variance analyses, the Tukey test and cluster analysis. Results and discussion. There was a statistical difference between the acerola genotypes studied. Three of them stood out as natural sources of vitamin C. In spite of fruit size, two acerola genotypes were found to have potential for fresh fruit production. In a general form, genotypes that presented a high [SS / TA] ratio had low vitamin C content. Conclusion. The acerola genotypes studied in Jaboticabal presented high variability, forming eleven groups in relation to fruit quality parameters.

Brazil / Malpigbia glabra / selection / agronomic characters / physicochemical properties / ascorbic acid

\section{Sélection préliminaire de génotypes d'acérola au Brésil.}

Résumé - Introduction. Les travaux d'amélioration de l'acérolier (Malpighia glabra) visent à l'obtention de plants donnant des fruits présentant des caractéristiques physiques et chimiques uniformes, y compris pour ce qui est de teneurs élevées en vitamine C, aptes à approvisionner le marché du fruit frais et de la pulpe congelée. Au Brésil, une grande variabilité de la qualité du fruit de l'acérolier est observée, particulièrement dans le cas des cerises issues de plants propagés par graines. Dans ce contexte, nos recherches ont tenté d'évaluer les caractéristiques physiques et chimiques des fruits de différents génotypes brésiliens d'acérolier. Matériel et méthodes. Seize génotypes d'acérolier ont été étudiés à Jaboticabal, État de São Paulo, Brésil. Un dispositif expérimental complètement randomisé avec seize traitements et six répétitions a été adopté. Chaque traitement a été représenté par un génotype. Plusieurs paramètres liés à la qualité du fruit, telle que largeur, longueur et poids du fruit, pourcentage de pulpe, solides solubles (SS), acidité titrable (AT), rapport [SS / AT] et teneur en vitamine C, ont été évalués dans les fruits des seize génotypes d'acérolier. Les résultats ont été soumis à des analyses de variance, au test de Tukey et à l'analyse des groupes. Résultats et discussion. Les génotypes d'acérolier étudiés ont différé statistiquement. Trois parmi eux se sont détachés en tant que sources naturelles de vitamine C. Malgré la dimension de leur fruit, deux génotypes d'acérolier se sont révélés avoir un bon potentiel pour la production de fruits frais. D'une façon générale, les génotypes qui ont présenté un haut rapport [SS / AT] ont eu une faible teneur en vitamine C. Conclusion. Les génotypes d'acérolier étudiés à Jaboticabal ont présenté une forte variabilité, formant onze groupes déterminés à partir de l'étude des paramètres de qualité du fruit.

Brésil / Malpighia glabra / sélection / caractère agronomique / propriété physicochimique / acide ascorbique
Fruits, 2007, vol. 62, p. 27-34 (C) 2007 Cirad/EDP Sciences All rights reserved DOI: $10.1051 /$ fruits:2006046 www.edpsciences.org/fruits

RESUMEN ESPAÑOL, p. 34 


\section{Introduction}

The importance of acerola (Malpighia glabra) is directly related to the chemical and nutritional status of the fruits, especially vitamin $\mathrm{C}$ content, that has increased acerola fruit demand in the market and motivated researchers, especially in countries with a tropical climate, such as Brazil.

During plant selection aiming to obtain new varieties, determination of genetic superiority has high relevance [1], mainly in relation to the most important characteristics for each species.

Breeding studies for acerola improvement have as an objective to obtain plants that produce fruits with uniform chemical and physical attributes, including high levels of vitamin $\mathrm{C}$, which can provision the market with fresh fruit and frozen pulp [2].

In Brazil, the research has been directed towards releasing new varieties, among which can be mentioned: Sertaneja [3], Olivier [4], UEL3-Dominga, UEL4-Lígia and UEL5-Natália [5]; UFRPE-7 and UFRPE-8 [6]. Nevertheless, vitamin C content depends on plant genetics, the maturity stage of fruits, harvest season, cultural methods adopted and other factors such as temperature, precipitation and insolation [7].

The physicochemical parameters are important indicators of maturation and internal and external quality of fruits [8], decisive factors for accomplishment of market demands. In this sense, research that studies acerola chemistry and indicates genetic material for fruit production with good external quality and high levels of vitamin $\mathrm{C}$ has a high relevance for Brazilian horticulture.

High variability in fruit quality is observed in Brazilian acerola crops, especially those propagated by seeds. In this area, the objective of our research was to evaluate the physical and chemical characteristics of fruits of sixteen acerola genotypes in Jaboticabal, São Paulo State, Brazil.

\section{Materials and methods}

Our study was carried out with acerola (Malpighia glabra) genotypes formed by seed propagation, from different mother plants obtained from farms in São Paulo State, and belonging to the Active Germplasm Bank of the University of São Paulo State, Brazil. They were identified as follows: Acer-1, Acer-2, Acer-3, Acer-4, Acer-5, Acer-6, Acer7, Acer-8, Acer-9, Acer-10, Acer-11, Acer-12, Acer-13, Acer-14, Acer-15 and Acer-16. The local climate is classified as Cwa with average precipitation of $1400 \mathrm{~mm} \cdot \mathrm{year}^{-1}$ and temperatures between (18.5 and 25.0$)^{\circ} \mathrm{C}$.

A completely randomized design with 16 treatments and 6 replications was used. Each treatment was represented by one of the 16 genotypes.

Acerola fruits were collected from different parts of the plants to guarantee homogeneous samples. Fruits were harvested at full maturity (according to color) and distributed into samples of 25 units, placed in paper bags and taken to the laboratory of horticultural products at São Paulo State University, Brazil. The methods used for physical and chemical analyses are described in the following section.

\subsection{Physical analyses}

Physical analyses of the acerola fruits collected concerned the usual parameters:

- Length and width were obtained with a digital paquimeter $(0.01 \mathrm{~mm}-300 \mathrm{~mm}$, Digimess) and expressed in $\mathrm{cm}$.

- Fruit weight was measured using a Sartorius brand precision balance ( $0.01 \mathrm{~g}$ precision) and expressed in $\mathrm{mg}$.

- Pulp percentage was obtained by passing the fruits through a depulper. A direct relation was established between both fruit and pulp weight, adopting fruit weight as $100 \%$, and obtaining the correspondent percentage of pulp.

\subsection{Chemical analyses}

For chemical analyses of the acerola fruits, titratable acidity, vitamin C content, soluble solids and the [soluble solids / titratable acidity] ratio were assessed [9].

To measure the titratable acidity, $20 \mathrm{~g}$ of macerated fruit pulp were taken from 
acerola fruits and brought to a final volume of $100 \mathrm{~mL}$ by adding distilled water. A $20-\mathrm{mL}$ sample was taken from the mixture and three to four drops of phthalein were used as an indicator. This suspension was titrated with $0.1 \mathrm{~N} \mathrm{NaOH}$. The results were expressed in terms of percentage.

The vitamin $\mathrm{C}$ content was defined with $5 \mathrm{~g}$ of fruit pulp taken from acerola and brought to a final volume of $100 \mathrm{~mL}$ by adding distilled water plus $1 \mathrm{~mL}$ of $1 \%$ amid solution. A $20-\mathrm{mL}$ sample was taken from the mixture and titrated with $1 \mathrm{~N}$ iodine. The results were expressed in $\mathrm{mg} \cdot 100 \mathrm{~g}^{-1}$ of fresh fruit.

Soluble solids, expressed as ${ }^{\circ}$ Brix, were measured with an "Abbe" refractometer.

After chemical analyses, the relation between soluble solids and titratable acidity was calculated.

\subsection{Data analyses}

The results were submitted to variance analyses and the Tukey test at 0.01 probability error [10]. A hierarchical classification (dendrogram) was obtained from the dissimilarity matrix using the UPGMA (Unweighted Pair Group Method with Arithmetic Average) method. All the calculations were performed using the SAS statistical program [11].

\section{Results and discussion}

For all the parameters adopted for fruit evaluation, the variance analyses showed significant differences among the acerola genotypes studied, suggesting variability in characters among the genotypes (tables I, II).

\subsection{Physical characters}

The Acer-13 genotype fruits presented the largest individual average weight; however, they did not statistically differ from the Acer10 genotype (table I), indicating that both have potential for consumption as fresh fruit, especially Acer-10, which presents, besides big fruits, better chemical quality than Acer-13 fruits. The lowest fruit weight observed (4.24 $\mathrm{g}$ for Acer-11) is above the $3.52 \mathrm{~g}$ registered by Semensato and Pereira [12] but below the (7.81 and 6.59) g averages, respectively, for the UFRPE-7 and UFRPE-8 mother plants [6]. In spite of relevant differences, all the genotypes studied presented weight values above the limit of $4 \mathrm{~g}$ required by the industry [13].

In relation to the average length and width of the fruits, significant variations among genotypes were registered (table I). The analysis of these parameters shows that the fruits have larger length than width, characterizing the fruit format as subglobose. The Acer-11 genotype presented the smallest fruits $(1.99 \mathrm{~cm}$ in length and $1.73 \mathrm{~cm}$ in width) and Acer-13 the largest fruits $(2.70 \mathrm{~cm}$ in length and $2.32 \mathrm{~cm}$ in width). Length values, in general, are above the $1.62-2.07 \mathrm{~cm}$ range reported by Semensato and Pereira [12] but compatible with the UFRPE-7 mother plant, with a $2.3 \mathrm{~cm}$ average [14]. All genotypes presented fruit length above the minimum $(1.5 \mathrm{~cm})$ demanded by the industry [13].

The pulp percentage of genotypes (table I) had a large range that showed high variability. The range from $38.58 \%$ (Acer-11) to $61.21 \%$ (Acer-13) is close to the 47.8 $58.9 \%$ range presented by Gomes et al. [2] and the 40.83-65.63\% obtained by Semensato and Pereira [12]; lower than the 59-75\% range shown by Aróstequi and Pennock [15] and higher than the $30 \%$ average reported by Lopes et al. [1]. However, the Acer-13, Acer-16, Acer-15, Acer-12 and Acer-8 genotypes did not significantly differ from each other. In the scientific literature, there is no standardized value considered ideal for pulp percentage of acerola fruit; thus, comparing the results of this work with the indicated value for citric fruits (40\%) [16], only Acer-11 is below it.

\subsection{Chemical characters}

The measurement of soluble solids showed that fruits from Acer-10 had the highest percentage $\left(7.75^{\circ} \mathrm{Brix}\right)$, though not statistically different from Acer-9, Acer-14, Acer-3 and Acer-6, while Acer-12 presented the lowest result: $5.25^{\circ}$ Brix (table II). These data are close to the $5.40-8.27^{\circ} \mathrm{Brix}$ indicated by 
Í.H.L. Cavalcante et al.

Table I.

Average values of some physical parameters in fruits of acerola genotypes studied in Brazil (Jaboticabal, SP).

\begin{tabular}{|c|c|c|c|c|}
\hline \multirow[t]{2}{*}{ Genotype } & Width & Length & \multirow{2}{*}{$\begin{array}{l}\text { Weight } \\
\text { (g) }\end{array}$} & \multirow{2}{*}{$\begin{array}{l}\text { Pulp percentage } \\
\text { (\%) }\end{array}$} \\
\hline & \multicolumn{2}{|c|}{$(\mathrm{cm})$} & & \\
\hline Acer-1 & $1.99 \mathrm{bcd}$ & $2.34 \mathrm{bcd}$ & $6.35 \mathrm{c}$ & 50.02 bcdef \\
\hline Acer-2 & 1.94 bcde & $2.24 \mathrm{~d}$ & $6.02 \mathrm{c}$ & 48.42 cdef \\
\hline Acer-3 & $2.07 \mathrm{abc}$ & $2.35 \mathrm{bcd}$ & $6.82 c$ & 46.54 defg \\
\hline Acer-4 & 1.92 bcde & $2.36 \mathrm{bcd}$ & $7.25 \mathrm{bc}$ & 50.48 bcdef \\
\hline Acer-5 & $2.06 \mathrm{bcd}$ & $2.41 \mathrm{bcd}$ & $6.42 \mathrm{c}$ & 45.57 defg \\
\hline Acer-6 & $1.99 \mathrm{bcd}$ & $2.33 \mathrm{bcd}$ & $6.29 c$ & 49.72 bcdef \\
\hline Acer-7 & $1.88 \mathrm{cde}$ & $2.32 \mathrm{bcd}$ & $5.80 \mathrm{~cd}$ & 44.44 efg \\
\hline Acer-8 & 1.97 bcde & $2.40 \mathrm{bcd}$ & $6.56 \mathrm{c}$ & 52.41 abcde \\
\hline Acer-9 & $1.81 \mathrm{de}$ & $2.28 \mathrm{~cd}$ & $7.12 \mathrm{bc}$ & $42.26 \mathrm{fg}$ \\
\hline Acer-10 & $2.00 \mathrm{bcd}$ & $2.53 a b$ & $8.62 a b$ & $42.89 \mathrm{fg}$ \\
\hline Acer-11 & $1.73 \mathrm{e}$ & $1.99 \mathrm{e}$ & $4.24 \mathrm{~d}$ & $38.58 \mathrm{~g}$ \\
\hline Acer-12 & $2.00 \mathrm{bcd}$ & $2.43 \mathrm{bcd}$ & $6.39 c$ & $54.36 \mathrm{abcd}$ \\
\hline Acer-13 & $2.32 \mathrm{a}$ & $2.70 \mathrm{a}$ & $9.94 \mathrm{a}$ & $61.21 \mathrm{a}$ \\
\hline Acer-14 & 1.94 bcde & $2.43 \mathrm{bcd}$ & $6.04 \mathrm{c}$ & $41.44 \mathrm{fg}$ \\
\hline Acer-15 & $2.17 \mathrm{ab}$ & $2.47 \mathrm{abc}$ & $7.08 \mathrm{bc}$ & $57.52 \mathrm{abc}$ \\
\hline Acer-16 & $2.07 \mathrm{abc}$ & $2.50 a b c$ & $7.28 \mathrm{bc}$ & $57.83 a b$ \\
\hline
\end{tabular}

Averages followed by the same letter in columns do not differ by the Tukey test at 0.01 probability error.

Table II.

Average values of some chemical parameters in fruits of acerola genotypes studied in Brazil (Jaboticabal, SP).

$\begin{array}{llccl}\text { Genotype } & \begin{array}{c}\text { Soluble solids } \\ \left({ }^{\circ} \text { Brix }\right)\end{array} & \begin{array}{c}\text { Titratable acidity } \\ (\%)\end{array} & \begin{array}{c}\text { [Soluble solids / } \\ \text { Titratable acidity] }\end{array} & \begin{array}{c}\text { Vitamin C } \\ \left(\mathrm{mg} \cdot 100 \mathrm{~g}^{-1}\right)\end{array} \\ \text { Acer-1 } & 6.35 \mathrm{de} & 0.63 \mathrm{~g} & 9.97 \mathrm{~b} & 665.22 \mathrm{de} \\ \text { Acer-2 } & 6.65 \mathrm{cde} & 0.72 \mathrm{efg} & 9.20 \mathrm{bc} & 887.61 \mathrm{abcd} \\ \text { Acer-3 } & 6.90 \mathrm{abcd} & 0.73 \mathrm{efg} & 9.46 \mathrm{bc} & 1028.95 \mathrm{ab} \\ \text { Acer-4 } & 6.80 \mathrm{bcd} & 0.69 \mathrm{fg} & 9.87 \mathrm{~b} & 772.51 \mathrm{bcde} \\ \text { Acer-5 } & 6.40 \mathrm{de} & 0.73 \mathrm{efg} & 8.95 \mathrm{bc} & 888.39 \mathrm{abcd} \\ \text { Acer-6 } & 6.90 \mathrm{abcd} & 0.80 \mathrm{def} & 8.57 \mathrm{~cd} & 751.44 \mathrm{cde} \\ \text { Acer-7 } & 5.80 \mathrm{efg} & 1.05 \mathrm{ab} & 5.53 \mathrm{e} & 1141.21 \mathrm{a} \\ \text { Acer-8 } & 5.40 \mathrm{fg} & 0.97 \mathrm{bc} & 5.59 \mathrm{e} & 967.59 \mathrm{abc} \\ \text { Acer-9 } & 7.55 \mathrm{ab} & 0.75 \mathrm{ef} & 10.03 \mathrm{~b} & 758.85 \mathrm{cde} \\ \text { Acer-10 } & 7.75 \mathrm{a} & 0.82 \mathrm{de} & 9.43 \mathrm{bc} & 731.54 \mathrm{cde} \\ \text { Acer-11 } & 6.85 \mathrm{bcd} & 0.78 \mathrm{ef} & 8.76 \mathrm{bc} & 800.21 \mathrm{bcde} \\ \text { Acer-12 } & 5.25 \mathrm{~g} & 0.90 \mathrm{~cd} & 5.81 \mathrm{e} & 880.16 \mathrm{abcd} \\ \text { Acer-13 } & 6.25 \mathrm{def} & 1.15 \mathrm{a} & 5.44 \mathrm{e} & 928.57 \mathrm{abcd} \\ \text { Acer-14 } & 7.35 \mathrm{abc} & 0.37 \mathrm{~h} & 19.39 \mathrm{a} & 723.74 \mathrm{cde} \\ \text { Acer-15 } & 6.55 \mathrm{cde} & 0.73 \mathrm{efg} & 8.95 \mathrm{c} & 575.48 \mathrm{e} \\ \text { Acer-16 } & 5.80 \mathrm{efg} & 0.78 \mathrm{ef} & 7.38 \mathrm{~d} & 1127.55 \mathrm{a}\end{array}$

Averages followed by the same letter in columns do not differ by the Tukey test at 0.01 probability error. 


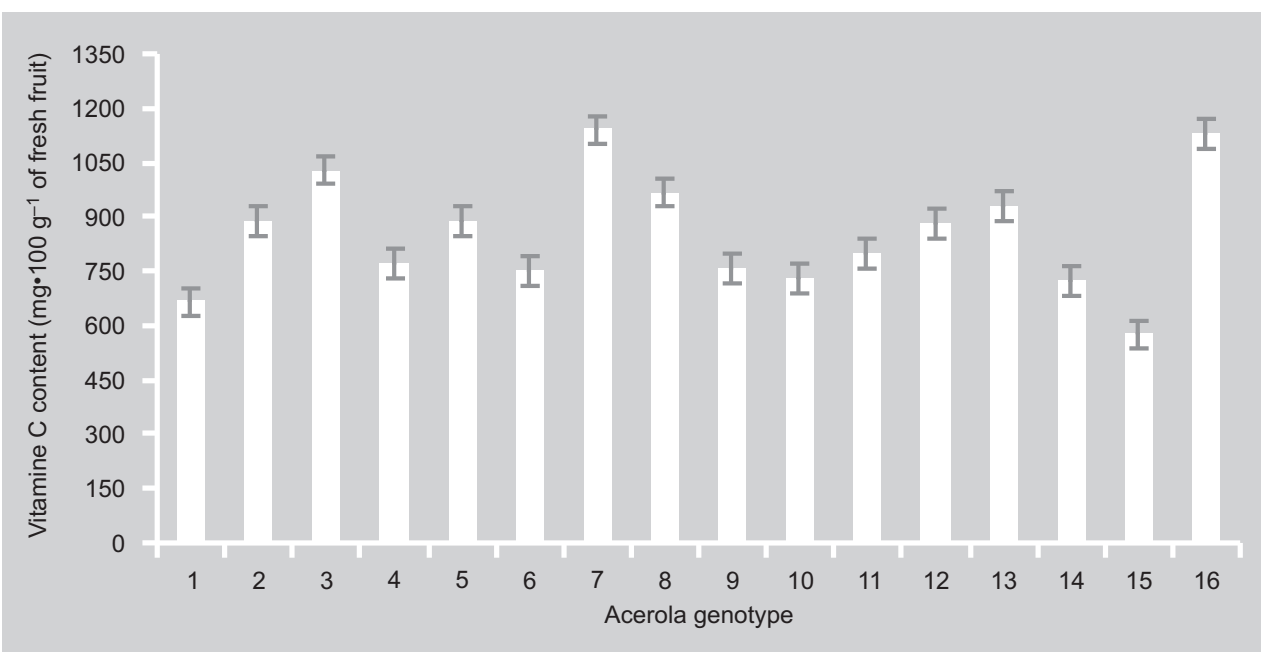

Figure 1.

Vitamin $\mathrm{C}$ content in fruits of acerola genotypes studied in Brazil (Jaboticabal, SP).

Semensato and Pereira [12] and to the 6.0 $11.59^{\circ}$ Brix registered by Matsuura et al. [17], but they are below the $9.2^{\circ}$ Brix reported by Vendramini and Trugo [18]. High values of soluble solids are important for consumption as fresh or processed fruit. For some fruits such as mango and orange, soluble solids values have been used as a maturity rate, but in acerola fruit this measurement is not a good parameter due to low data confidence, according to Lopes et al.'s [1] study.

The Acer-14 genotype presented the lowest titratable acidity, while Acer-13 and Acer7 had similar and the highest titratable acidity, $1.15 \%$ and $1.05 \%$, respectively (table II). These data are close to results quoted in the literature, such as $0.95 \%$ for the UFRPE-7 mother plant [14], 0.94\% [1] and the 0.69$1.65 \%$ range [17] also in a study about different acerola genotypes. Possibly, the high values reported here are a function of the high organic acid content in acerola fruit, as also reported by Assis et al. [19]. According to Nascimento et al. [20], high titratable acidity is important for fruit processing, as it reduces the necessity for addition of artificial acid components, although this is not a limiting factor in genotype selection where other fruit quality parameters are satisfactory. On the other hand, low titratable acidity, as registered in the Acer-14 genotype, is relevant for consumption as fresh fruit, as proposed by Seymour and Tucker [21].

The soluble solids and titratable acidity characteristics, individually regarded, can represent a false indicative of fruit flavor, while the [soluble solids / titratable acidity] ratio is considered a practical form, mainly for consumption as fresh fruit. Kimball [22] explains that the [soluble solids / titratable acidity] ratio as a technological variable of fresh fruit quality is based on the competition of sugars and acids by the same perception site of the tongue. Our results for the [soluble solids / titratable acidity] ratio ranged between 5.44 and 19.39. Acer-12, Acer-8, Acer-7 and Acer-13 showed the lowest ratio with no statistical difference and Acer-14 the highest one (table II). The literature reports results such as 4.24-11.59 [17] and $0.32-0.95$ [12]. This rate is a function of the equilibrium degree between sugars and organic acids in fruits.

Vitamin $\mathrm{C}$ contents ranged from $575.48 \mathrm{mg} \cdot 100 \mathrm{~g}^{-1}$ of fresh fruit (Acer-15) to $1141.21 \mathrm{mg} \cdot 100 \mathrm{~g}^{-1}$ of fresh fruit (Acer-7). There was no statistical difference among the Acer-7, Acer-16, Acer-3, Acer-8, Acer-13, Acer-5, Acer-2 and Acer-12 genotypes (table II, figure 1). These contents are close to the results related by Semensato and Pereira [12] and Assis et al. [19], but below those of Matsuura et al. [17] (1820 mg.100 gof fresh fruit), Nogueira et al. [6] $\left(1682.67 \mathrm{mg} \cdot 100 \mathrm{~g}^{-1}\right.$ of fresh fruit) and Musser et al. (1434 mg $100 \mathrm{~g}^{-1}$ of fresh fruit) [23].

Contents of vitamin $\mathrm{C}$ for the Acer- 1 and Acer-15 genotypes were very low in comparison with the other genotypes studied. In 


\section{Figure 2.}

Cluster diagram of acerola genotypes, obtained with physical and chemical variables studied in Brazil (Jaboticabal, SP).

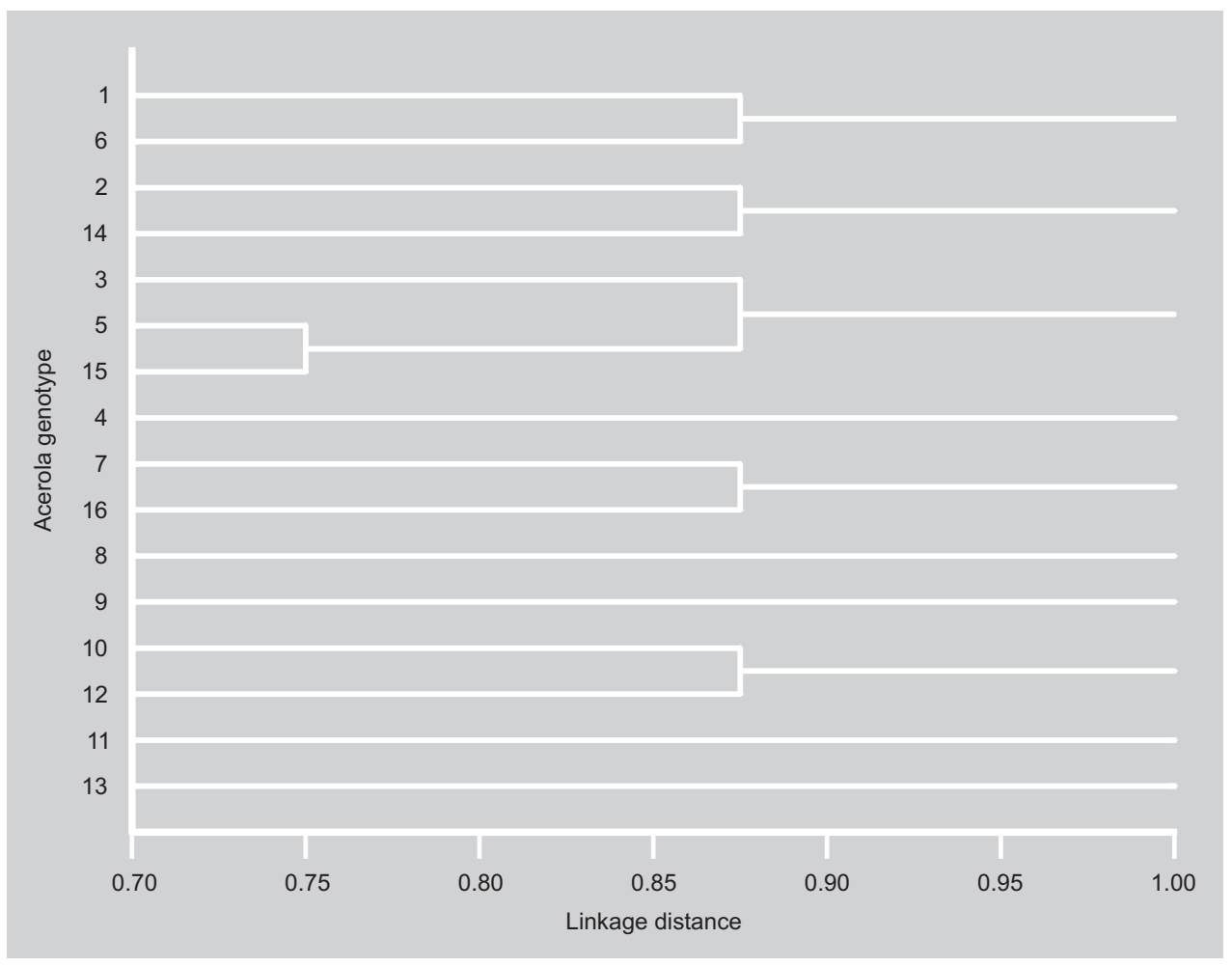

general, acerola fruit has higher vitamin C contents than other fruits such as passion fruit [20], orange [24], rambutan and carambola [25].

In our study, a negative relation between vitamin C content and the [soluble solids / titratable acidity] ratio was registered, i.e., genotypes that presented the highest [soluble solids / titratable acidity] ratio (Acer-14, Acer-9, Acer-1 and Acer-4) had low vitamin C content. Matsuura et al. [17] explain that there is possibly a direct relation between total acids and vitamin $\mathrm{C}$ content in acerola fruit. This note, whether confirmed by further studies, indicates that selection of acerola genotypes cannot consider both variables.

\subsection{Groups identified}

The cluster analysis done with the data obtained from the fruit physical and chemical parameters studied presents high dissimilarity (> 75.0\%) among the acerola genotypes. In spite of the high dissimilarity observed, the genotypes were clustered into eleven distinct groups according to the dendrogram obtained via the UPGMA method (figure 2). Group I comprises Acer-1 and Acer-6; group II was formed by Acer-2 and Acer-14; group III had Acer-3; group IV contained Acer-5 and Acer-15; group $\mathrm{V}$ was formed by Acer-4; group VI comprised Acer7 and Acer-16; group VII was formed by Acer-8; group VIII was formed by Acer-9; group IX contained Acer-10 and Acer-12; group X was formed by Acer-11 and, finally, group XI by Acer-13. According to these results, five genotypes (Acer-4, Acer-8, Acer9, Acer-11 and Acer-13) are 100\% individually different from the others, which shows the genetic variability among them, an important and depreciative characteristic of Brazilian acerola crops.

\section{Conclusions}

In conclusion, our results showed the formation of eleven groups, which indicates 
high variability among the acerola genotypes studied in relation to fruit quality parameters. In this way, some genotypes presented potential for consumption as fresh fruit and others for industry. However, further studies are needed to obtain new parameters of plant phenology, propagation and yield to obtain a new cultivar and standardize acerola crops.

\section{References}

[1] Lopes R., Bruckner C.H., Cruz C.D., Lopes M.T.G., Freitas G.B., Repetibilidade de características do fruto de aceroleira, Pesqui. Agropecu. Bras. 36 (2001) 507-513.

[2] Gomes J.E., Perecin D., Martins A.B.G., Almeida E.J., Variabilidade fenotípica em genótipos de acerola, Pesqui. Agropecu. Bras. 35 (2000) 2205-2211.

[3] Gonzaga Neto L., Bezerra J.E.F., Acerola Sertaneja, in: Donadio L.C. (Ed.), Novas variedades brasileiras de frutas, Soc. Bras. Frutic., Jaboticabal, Brazil, 2000.

[4] Kanno O.Y., Rizzi L.C., Kavati R., Acerola Olivier, in: Donadio L.C. (Ed.), Novas variedades brasileiras de frutas, Soc. Bras. Frutic., Jaboticabal, Brazil, 2000.

[5] Carpentieri-Pípolo V., Destro D., Prete C.E.C., Gonzáles M.G.N., Popper I.O., Zanata S., Silva F.A., Seleção de genótipos parentais de acerola com base na divergência genética multivariada, Pesqui. Agropecu. Bras. 35 (2000) 1613-1619.

[6] Nogueira R.J.M.C., Moraes J.A.P.V., Burity H.A., Silva Júnior J.F., Efeito do estádio de maturação dos frutos nas características físico-químicas de acerola, Pesqui. Agropecu. Bras. 37 (2002) 463-470.

[7] Nakasone N.Y., Yamante G.M., Miyashita R.K., Selection, evaluation and naming of acerola (Malpighia glabra L.) cultivars, Hawaii Agric. Exp. Stn. 65 (1968) 1-19.

[8] Washowicz C.M., Carvalho R.I.N., Fisiologia vegetal e pós-colheita, Champangnat, Curitiba, Brazil, 1992.

[9] Anon., Métodos físicos e químicos para análise de alimentos, Inst. Adolfo Lutz, São Paulo, Brazil, 1976.
[10] Ferreira P.V.F., Estatística experimental aplicada à agronomia, EDUFAL, Maceió, Brazil, 2000.

[11] Anon., SAS/STAT user's guide, version 4.0.2, SAS Inst. Inc., Cary, USA, 2000.

[12] Semensato L.R., Pereira A.S., Características de frutos de genótipos de aceroleira cultivados sob elevada altitude, Pesqui. Agropecu. Bras. 35 (2000) 1529-1536.

[13] Anon., Normas soluções fruta a fruta: acerola, IBRAF, São Paulo, Brazil, 1995.

[14] França V.C., Narain N., Caracterização química dos frutos de três matrizes de acerola (Malpighia emarginata D.C.), Cienc. Tecnol. Aliment. 23 (2003) 157-160.

[15] Aróstegui F., Pennock W., La acerola, Publ. Miscelánea 15, Rios Piedras, Puerto Rico, 1995, 9 p.

[16] Chitarra M.I.F., Chitarra A.B., Pós-colheita de frutos e hortaliças, ESAL/FAEPE, Lavras, Brazil, 1990.

[17] Matsuura F.C.A.U., Cardoso R.L., Folegatti M.I.S., Oliveira J.R.P., Oliveira J.A.B., Santos D.B., Avaliações físico-químicas em frutos de diferentes genótipos de acerola (Malpighia punicifolia I.), Rev. Bras. Frutic. 23 (2001) 602-606.

[18] Vendramini A.L., Trugo L.C., Chemical composition of acerola fruit (Malpighia puniciflora L.) at three stages of maturity, Food Chem. 71 (2000) 195-198.

[19] Assis S.A., Lima D.C., Oliveira O.M.M.F., Activity of pectinmethylesterase, pectin content and vitamin $\mathrm{C}$ in acerola fruit at various stages of fruit development, Food Chem. 74 (2001) 133-137.

[20] Nascimento T.B., Ramos J.D., Menezes J.B., Características físico-químicas do maracujá amarelo (Passiflora edulis f. flavicarpa Deg.) produzido em diferentes épocas, Rev. Bras. Frutic. 20 (1998) 33-38.

[21] Seymour G.B., Tucker G.A., Biochemistry of fruit ripening, Chapman \& Hall, London, England, 1996.

[22] Kimball D.A., Factors affecting the rate of maturation of citrus fruits, Proc. Fla. State Hortic. Soc. 97 (1984) 40-44.

[23] Musser R.S., Lemos M.A., Lima V.L.A.G., Melo E.A., Lederman I.E., Santos V.F., Características físico-químicas de acerola do 
Í.H.L. Cavalcante et al.

banco ativo de germoplasma em Pernambuco, Cienc. Tecnol. Aliment. 24 (2004) 556561.

[24] Domingues E.T., Tulmann Neto A., Teófilo Sobrinho J., Mattos Júnior D., Pompeu Júnior J., Figueiredo J.O., Seleção de variedades de laranja quanto à qualidade do fruto e período de maturação, Laranja 24 (2003) 471-490.

[25] Moy J.H., Wong L., The efficacy and progress in using radiation as a quarantine treatment of tropical fruits - a case study in Hawaii, Radiat. Phys. Chem. 63 (2002) 397401.

\section{Selección preliminar de genotipos de acerola en Brasil.}

Resumen - Introducción. Los estudios de mejora de la acerola (Malpighia glabra) pretenden obtener plantones que aporten frutos, que presenten características físicas y químicas uniformes, incluso en lo que se refiere a los altos contenidos de vitamina $\mathrm{C}$, capaces de abastecer el mercado del fruto fresco y de la pulpa congelada. En Brasil, se observa una gran variabilidad de la calidad del fruto de la acerola, concretamente en el caso de las cerezas procedentes de plantones propagados mediante semillas. En este contexto, nuestros estudios procuraron evaluar las características físicas y químicas de los frutos de diferentes genotipos brasileños de la acerola. Material y métodos. Se estudiaron dieciséis genotipos de acerola en Jaboticabal, estado de Sao Paolo, Brasil. Se adoptó un dispositivo experimental completamente randomizado con dieciséis tratamientos, y seis repeticiones. Se representó cada tratamiento por un genotipo. Se evaluaron en los frutos de los dieciséis genotipos de acerola varios parámetros relacionados a la calidad del fruto, como, por ejemplo, la anchura, el largo y el peso del fruto, el porcentaje de la pulpa, los sólidos solubles (SS), la acidez triturable (AT), la relación [SS / AT] y el contenido en vitamina C. Los resultados se sometieron a análisis de varianza, así como a la prueba de Tukey, y al análisis de los grupos. Resultados y discusión. Difirieron estadísticamente los genotipos estudiados de acerola. Tres de ellos se desprendieron en tanto que fuentes naturales de vitamina C. A pesar de la dimensión de fruto, dos genotipos de acerola resultaron poseer un buen potencial para la producción de frutos frescos. De un modo general, los genotipos que presentaron una relación alta [SS / AT] tuvieron un escaso contenido de vitamina C. Conclusión. Los genotipos de acerola estudiados en Jaboticabal presentaron una alta variabilidad, formando once grupos determinados a partir del estudio de los parámetros de la calidad del fruto.

\section{Brasil / Malpighia glabra / selección / características agronómicas / propiedades fisicoquímicas / ácido ascórbico}

